\title{
MONUMEN MEGALITIK DAN \\ TRANSPORTASI BAHANNYA \\ Analisis Terhadap Beberapa Faktor Yang Berpengaruh
}

\author{
Lutfi Yondri \\ (Balai Arkeologi Bandung)
}

\begin{abstract}
Megalithic monuments in Nusantara are generally found on plateaus, for example on hill tops, mountain slopes, and other remote locations. A big question often raised on how the prehistoric people could move such huge and heavy boulders to build their monuments. It is assumed that to build those megalithic monuments, various factors were involved, i.e. the landscape, technology, and leaderships as well.
\end{abstract}

Key words: megalitik, monumen, lokasi, pengangkutan, masyarakat

\section{PENDAHULUAN}

Situs megalitik di masa lalu, merupakan salah satu bagian dari satu kawasan permukiman secara makro. Selain situs megalitik, di kawasan tersebut juga terdapat variabel-variabel lain seperti lahan hunian/tempat tinggal, lahan pertanian basah/kering, sumber air, dan lokasi yang dijadikan sebagai tempat pengambilan bahan untuk dijadikan monumen megalitik.

Apabila diperhatikan temuan-temuan megalitik yang telah diteliti oleh para ahli selama ini, muncul satu pertanyaan bagaimana cara masyarakat memindahkan bahan monumen megalitik tersebut di masa lalu. Beberapa monumen tersebut di samping berukuran besar, tidak sedikit di antaranya memiliki tonase yang cukup berat. Bahkan bila diukur dengan tenaga manusia biasa sangat sulit untuk memindahkannya. Menurut Haris Sukendar, kemungkinan dalam proses pendirian dan pembangunan monumen megalitik tersebut selain menggunakan teknik rekayasa penataan batu yang sangat teliti, juga diperkirakan dalam prosesi tersebut diperlukan tenaga ratusan atau ribuan manusia (Sukendar 1996: 112).

Melihat proses perkembangan masyarakat khususnya masyarakat pendukung budaya megalitik di masa lalu, sebenarnya untuk pengerahan manusia dalam jumlah ratusan atau bahkan dalam jumlah ribuan agak sulit untuk dilacak. Dari hasil penelitian para ahli diasumsikan bahwa masyarakat pendukung budaya megalitik khususnya merupakan kelompok masyarakat yang sudah hidup menetap di desa-desa kecil semacam pedukuhan. Perkampungan tersebut terletak di daerah pegunungan atau daerah perbukitan yang dikelilingi oleh dinding batu atau semak berduri yang 
ditujukan untuk mencegah serangan-serangan musuh. Oleh sebab itu bentuk desanya dibuat berundak-undak dan dibentuk dengan susunan batu (Soejono 1990: 201).

Dari dasar pemikiran bentuk perkampungan megalitik di atas, dapat diperkirakan bahwa jumlah penduduk dari satu perkampungan megalitik tersebut tidak akan banyak, dalam arti tidak mencapai jumlah ratusan apalagi ribuan orang. Tentunya untuk melibatkan masyarakat dalam jumlah ratusan atau ribuan tersebut pada masa lalu merupakan hal yang sulit. Masalah pengangkutan bahan/monumen megalitik tersebut sangat menarik untuk dibahas, karena seringkali pada beberapa kasus megalitik dinyatakan bahwa baik monumen, atau bahan, atau tempat pembuatannya tidak satu lokasi dengan lokasi penemuan (situs)nya. Untuk menjawab pertanyaanpertanyaan ini, dicoba dibahas tentang bagaimana posisi atau keletakan situs megalitik dalam lingkungan geografis, serta faktor apa saja yang dapat memberikan kontribusi pada masa lalu dalam proses pengangkutannya, sehingga monumen megalitik tersebut dapat sampai di lokasi pendiriannya.

\section{POSISI DAN KELETAKAN SITUS MEGALITIK}

Dengan membandingkan lokasi permukiman pada daerah-daerah tertentu yang masih melanjutkan tradisi budaya megalitik, dapat diperkirakan bahwa lingkungan hunian masyarakat masa bercocok tanam

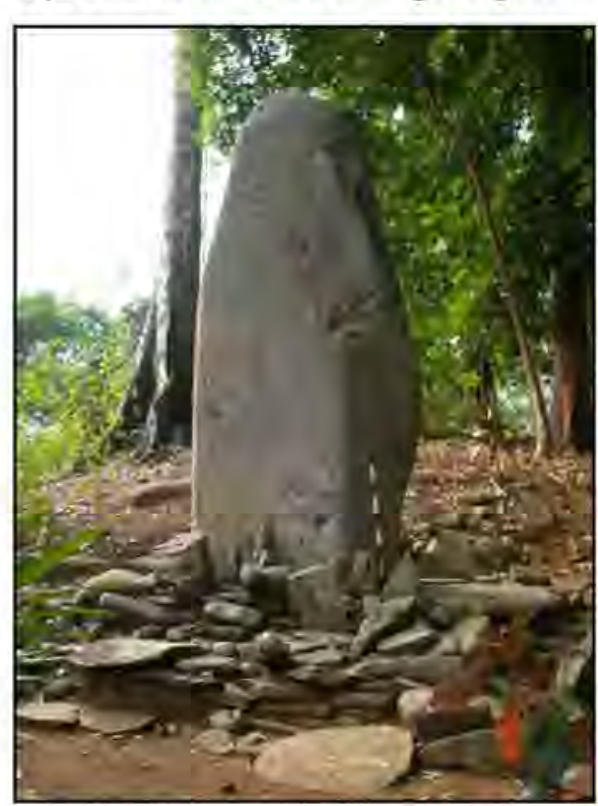

Menhir tinggi $4 \mathrm{~m}$, di situs Tugu Gede, Sukabumi, terbuat dari batu andesit massif yang didirikan di kawasan tanah berkontur bergelombang.

(Foto. Dok. Balar Bdg, 2004) yang juga sekaligus sebagai pendukung budaya megalitik, tidak jauh berbeda. Dari hasil penelitian arkeologis yang telah dilakukan oleh para ahli selama ini, terlihat bahwa masyarakat prasejarah pada beberapa hal cenderung untuk memanfaatkan sumber daya alam yang tersedia di lingkungannya untuk pemenuhan kebutuhannya. Akan tetapi dalam halhal tertentu, seperti yang berhubungan dengan kebutuhan yang bersifat sakral, apabila sumber bahannya tidak mereka peroleh dari lingkungan sekitar, tampaknya mereka berusaha untuk memenuhi kebutuhan tersebut walaupun harus menempuh jarak tertentu. Salah satu contoh dari hal tersebut terlihat dalam kegiatan pendirian monumen-monumen yang ditujukan untuk pemujaan atau pengagungan arwah leluhur yang didirikan oleh masyarakat pendukung tradisi budaya megalitik di kawasan Nusantara di masa lalu. 
Apabila diperhatikan secara seksama dari data situs-situs megalitik yang ada, kondisi geografis situs-situs megalitik tersebut dapat dikelompokkan menjadi dua. Pertama adalah situs-situs megalitik yang terletak di tempat yang tinggi secara natural, kedua adalah situs-situs megalitik yang sengaja dibuat tinggi atau ditinggikan. Situs-situs megalitik yang termasuk dalam kelompok pertama pada umumnya terletak pada daerah perbukitan. Adapun situs megalitik yang termasuk dalam kelompok kedua adalah situs-situs megalitik yang berada bukan pada lingkungan perbukitan atau di dataran.

Terjadinya penempatan lokasi situs megalitik yang demikian karena arwah nenek moyang dianggap bertempat tinggal di puncak gunung atau bukit, dan anggapan puncak gunung sebagai dunia arwah yang mempunyai kekuatan gaib (Sutaba, 1999:19). Dapat diasumsikan bahwa dalam tradisi budaya megalitik tersebut, konsep ketinggian merupakan faktor utama dari pemilihan lokasi untuk dijadikan sebagai tempat pemujaan.

Dari kedua pengelompokan kondisi geografis situs megalitik tersebut, keletakan lokasi yang menjadi sumber bahan atau perbengkelan monument pun dapat

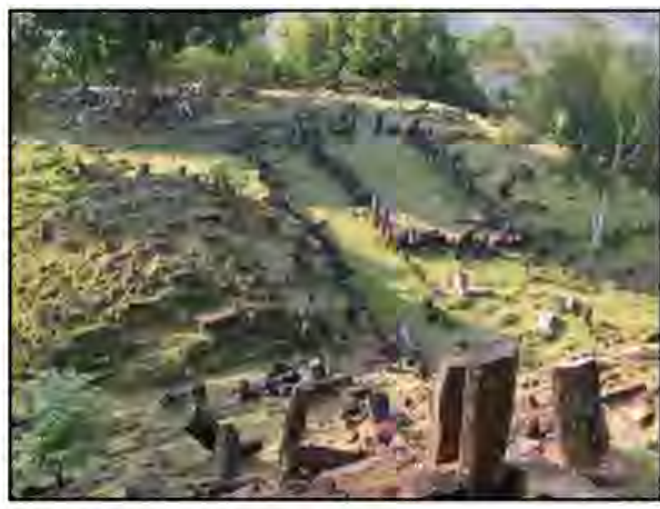

Tinggalan bagunan punden berundak di puncak Gunung Padang, terbuat dari susunan balok-balok andesit dengan bobot balok batuan ratusan kilogram.

(Foto. Dok. Balar Bdg, 2006) berada pada posisi yang sejajar, lebih rendah, atau terletak lebih tinggi dari lokasi situs. Hal tersebut akan berpengaruh terhadap cara pengangkutan monumen dari lokasi sumber bahan atau perbengkelan menuju situs pendiriannya.

Apabila situs megalitik terletak sejajar atau lebih rendah dari lokasi sumber bahan atau perbengkelannya, mungkin proses pengangkutannya tidak begitu sulit. Akan tetapi pada kasus-kasus situs megalitik yang berada di tempat-tempat yang tinggi yang memiliki monumen yang cukup berat dan besar, akan membawa konsekuensi terhadap sulitnya pengangkutan bahan atau monumen-monumen tersebut.

Berdasarkan data tersebut dicoba dikemukakan beberapa faktor kemungkinan yang memiliki pengaruh yang sangat menentukan, sehingga monumen-monumen megalitik yang berukuran besar dan berat tersebut dapat dibawa dari lokasi sumber bahan atau perbengkelan ke situs pendiriannya. 


\section{BEBERAPA FAKTOR BERPENGARUH DALAM PROSES PENGANGKUTAN}

Pada saat terjadinya proses pemindahan bahan untuk monumen megalitik dari lokasi pembuatan, atau sumber, menuju situs pendiriannya tentu ada faktor-faktor yang sangat berpengaruh, sehingga monumen megalitik dengan tonase yang besar tersebut dapat sampai di lokasi pendiriannya. Secara garis besar faktor-faktor tersebut dikelompokkan atas tiga, yang masing-masing sangat berkaitan erat dengan tingkat pengetahuan, serta keadaan masyarakat di masa itu. Tiap-tiap faktor tersebut adalah sebagai berikut:

\section{Teknologi Sederhana}

Keadaan alam atau lintas geografi wilayah yang menghubungkan antara lokasi sumber bahan dan situs arkeologis, berupa daerah lereng apalagi dengan permukaan lahan yang datar, merupakan faktor yang cukup memberikan kemudahan bagi jalur pengangkutan bahan maupun produk jadi yang akan dijadikan sebagai monumen budaya megalitik. Hal tersebut akan sangat berpengaruh lagi apabila keduanya berada pada ketinggian yang berbeda, dengan kata lain lokasi situs terletak lebih rendah dibanding lokasi sumber bahan. Dengan sendirinya jalur yang demikian akan memudahkan untuk pengangkutan material tersebut baik yang masih dalam bentuk bahan maupun produk jadi dari sumber atau perbengkelan menuju situs.

Akan tetapi, bila antara sumber bahan dan lokasi pembuatan monumen dengan lokasi pendiriannya memiliki jarak yang tidak pendek dengan bentang alam yang tidak mudah, kemudian ditambah lagi dengan ukuran monumen yang begitu besar, tentunya tingkat kesulitan dalam proses pengangkutannya cukup tinggi. Dalam hal ini tentunya pengetahuan teknologi sederhana yang dimiliki oleh masyarakat megalitik pada saat itu memiliki peran yang sangat dominan dalam proses pengangkutan monumen tersebut.

Berdasarkan hasil kajian dari ilmuwan-ilmuwan terdahulu, diperkirakan sistem roda dengan menggunakan gelondongan kayu sudah dikenal sejak masa prasejarah. Salah satu bukti tertua penggunaan kayu gelondongan sebagai jalur pemindahan material di masa lalu antara lain yang disebut sebagai Eclipse Track, terdiri dari hamparan kayu gelondongan, yang berasal dari 3500 tahun yang lalu (Renfrew dan Bahn, 1996:315). Sistem pengangkutan yang demikian juga digunakan oleh masyarakat pendukung budaya megalitik yang ada di kawasan Nusantara pada masa lalu. Hal itu terlihat dari hasil dokumentasi proses pemindahan monumen megalitik di pulau Nias sebelum tahun 1920 an yang didokumentasikan oleh van Eerde. Dari pendokumentasian tersebut terlihat adanya gelondongan-gelondongan kayu dalam jumlah banyak yang diletakkan di sepanjang jalur pemindahan monumen (Taylor dan Aragon 1992: 72). Data ini juga didukung oleh pertanggalan persebaran budaya 
megalitik di Indonesia, yang bila dibandingkan dengan awal perkembangan di daerah lain di luar Indonesia, tampak lebih muda. Diperkirakan awal masuknya budaya tersebut ke Indonesia adalah masa bercocok tanam yaitu sekitar tahun 2500 SM.

Penggunaan teknologi sederhana dalam pemindahan bahan/monumen megalitik ini juga dapat dilihat dalam upacara tarik batu di Sumba Barat. Bongkahan besar batukapur dengan berat antara 10 sampai 30 ton yang akan dijadikan sebagai monumen diangkut dengan menempatkannya di dalam wadah kayu yang disebut tena, kemudian ditarik ke kampung yang berada di atas bukit (Barbier dan Newton, 1988: 136). Diuraikan oleh Haris Sukendar (1993), bahwa upacara tarik batu itu dapat berlangsung berminggu-minggu, tergantung dari jarak yang ditempuh. Upacara ini biasanya dipimpin/dilaksanakan oleh marapu taghora karaka dan inna mate-ame mate. Seseorang yang ditunjuk oleh pemesan naik di atas batu untuk memimpin penarikan batu. Di saat batu mulai ditarik, pemilik batu juga melaksanakan upacara yang disertai sesaji berupa babi, kerbau, sirih, pinang, dan tembakau untuk orang-orang yang menarik batu. Setiap hari bahan-bahan itu harus disediakan. Jika terjadi hambatan ketika menarik batu, maka dilakukan pembacaan doa bersama disertai dengan menyebarkan nasi kuning dan menyebutkan mantera yang berbunyi liana sagaito kaguloge nabarara liana sawitu kagutara wemete yang berarti semoga roh-roh (jiwa) kekuatan jangan menghambat (mengikat). Pada waktu sudah akan sampai ke desa (tempat) yang dituju, maka diadakan upacara dengan disertai pembacaan mantera yang berbunyi pakatakogu limadara pawitugu, oraboga waisagubina bowagulara yang artinya semua sudah selesai dan rintangan sudah dapat diatasi (Sukendar, 1993:222-224).

\section{Pemimpin dan Kekuasaan}

Pada waktu tradisi megalitik berkembang dengan pesat yaitu di masa perundagian, diduga telah terbentuk masyarakat megalitik. Pada waktu itu penduduk sudah tinggal menetap di desa-desa kecil semacam pedukuhan atau perkampungan (village), hidup bertani dan mengembangbiakkan binatang, baik untuk keperluan hidup sehari-hari maupun untuk keperluan upacara-upacara tertentu. Di tiap-tiap dukuh terdapat beberapa tempat tinggal yang dibangun secara tidak beraturan. Pola-pola perkampungan atau tempat tinggal di masa itu umumnya ditentukan oleh beberapa faktor fisik seperti topografi, iklim, dan potensi pertanian (Soejono 1990: 196-197). Salah satu contoh bentuk perkampungan yang demikian adalah perkampungan masyarakat Kampung Lebak Cibedug yang bermukim di sekitar situs megalitik Lebak Cibeduk, Banten Selatan, dengan denah keletakan tempat tinggal, lahan persawahan, lahan upacara (punden berundak), sebagaimana terlihat pada gambar denah keletakan permukiman berikut. 


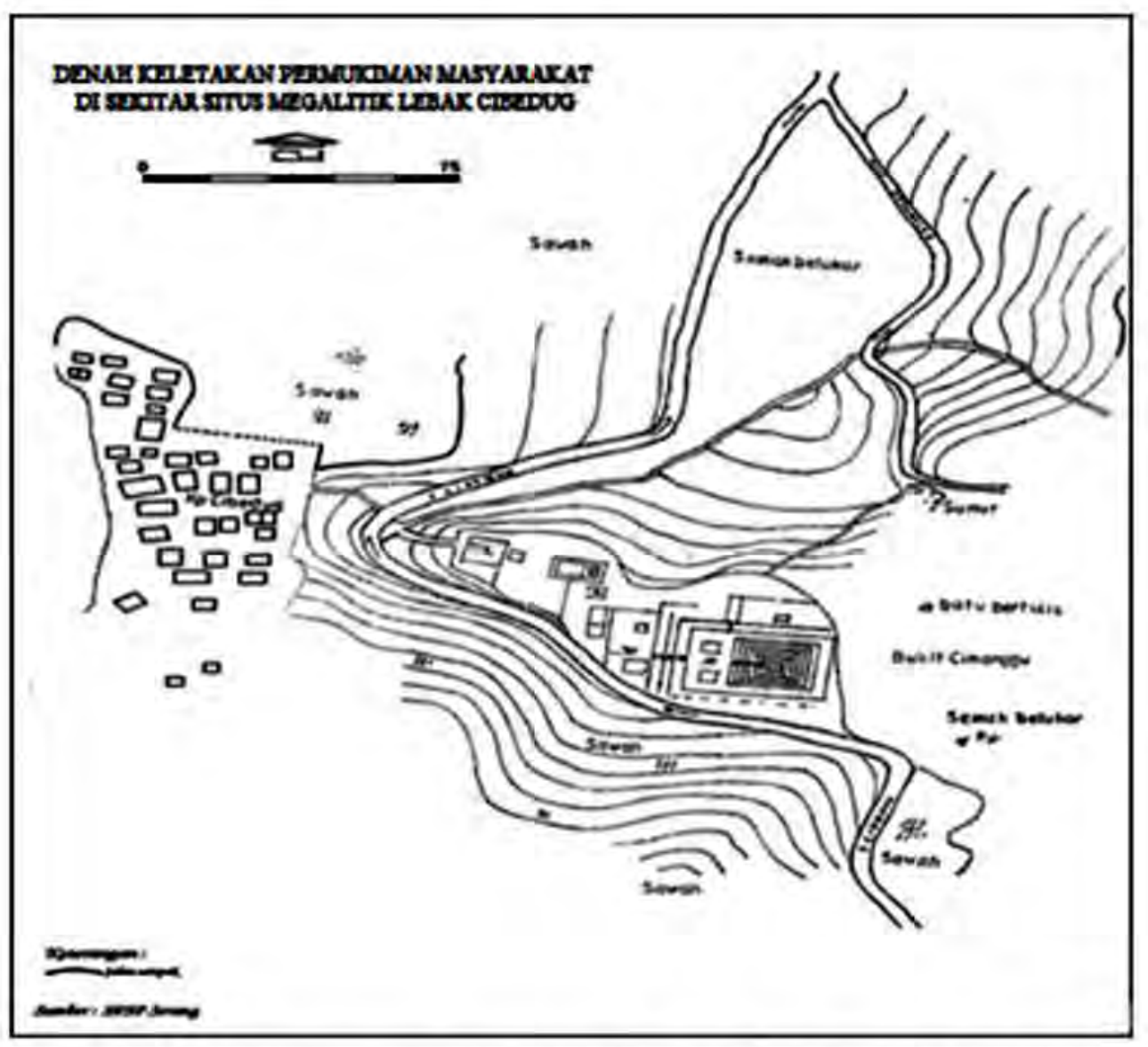

Besar kemungkinan masyarakat yang hidup dalam lingkungan pedukuhan pada masa itu tidak jauh berbeda dengan keadaan masyarakat Lebak Cibedug. Masyarakat pada saat itu bukan seperti kumpulan masyarakat yang heterogen seperti sekarang ini, tetapi merupakan kumpulan masyarakat yang homogen yang memiliki satu sistim kepercayaan serta umumnya hidup dalam kebersamaan. Kehidupan yang homogen dan sudah menetap di satu tempat tersebut, tentunya sangat mendukung pesatnya pertumbuhan dan perkembangan penduduk. Pada masa tersebut diperkirakan perkembangan tatanan masyarakat dengan perbedaan status sosial atau pelapisan masyarakat sudah mulai ada. Menurut Koentjaraningrat ada beberapa alasan tertentu untuk menganggap satu kedudukan yang khusus lebih tinggi dari kedudukan yang lain dalam satu masyarakat. Alasan-alasan tersebut dapat ditimbulkan oleh : a). kualitas dan kepandaian, b). tingkat umur yang senior, c). sifat keaslian, d). keanggotaan kaum kerabat kepala masyarakat, e). pengaruh dan kekuasaan, f). pangkat, dan g). kekayaan dan harta benda (Koentjaraningrat 1981: 178).

Dari pelapisan sosial di atas, dapat diperkirakan dalam kelompok masyarakat megalitik yang masih sederhana tersebut seorang kepala suku 
kemungkinan dapat terpilih karena alasan kualitas dan kepandaian, senioritas, atau karena pengaruh dan kekuasaannya. Pada butir a dan e tersebut, terdapat kemungkinan seorang kepala suku merupakan seorang yang pemberani dan memiliki pengaruh serta kekuasaan, yang tentunya disegani, dihormati, dan kemungkinan juga ditakuti oleh masyarakatnya.

Dalam sistem kepemimpinan kepala suku yang demikian dalam satu masyarakat yang homogen, tidak tertutup kemungkinan seorang kepala suku berkuasa penuh dalam masyarakatnya. Dengan kekuasaannya itu dia dapat melaksanakan apa yang diinginkannya. Haris Sukendar dalam pidato pengukuhannya sebagai Ahli Peneliti Utama, mengatakan bahwa "dalam pembuatan piramida di Mesir ada unsur-unsur pemaksaan, bahkan bukan tidak mungkin bagi pekerja yang sakit langsung dikubur karena tidak lagi efektif dan efisien". Begitu juga dengan pendirian bangunan megalitik. Pekerjaan yang melibatkan tenaga yang cukup banyak ini tentunya tidak mungkin dilaksanakan tanpa ada struktur organisasi yang kuat, dengan koordinasi aktif terletak pada seorang penguasa yang didukung oleh pembantu-pembantunya. Berdasarkan hasil penelitian van Heine Geldern dan Rumbi Mulia diketahui bahwa pembuatan dan pendirian monumen megalit sangat erat kaitannya dengan usaha untuk menjaga martabat dan kedudukan serta kemasyhuran, di samping untuk menjamin ketentraman arwah nenek moyang yang meninggal. Oleh karena itu, di samping mempunyai kaitan religi, maka pembuatan dan pendirian bangunan megalit berkait erat dengan martabat, status, kedudukan sosial, serta keadaan ekonomi pendirinya (Sukendar 1996: 117). Dari hal tersebut jelaslah bahwa di sini muncul seorang penguasa yang tentunya sangat dipatuhi oleh masyarakatnya.

Apabila diperhatikan hasil penelitian Rumbi Mulia (1980) dalam tulisannya Nias: The Only Older Megalithic Tradition In Indonesia, terlihat bahwa faktor penguasa sebagai penggerak dalam translokasi bahan/monumen megalitik tersebut tampaknya juga pernah terjadi di Indonesia. Dalam tulisan tersebut diperlihatkan bagaimana cara membawa batu (menhir) yang akan dijadikan sebagai lambang penguasa atau pemimpin. Digambarkan dengan berdiri di atas batu, si sponsor pembuatan monumen megalitik tersebut mengayun-ayunkan pedangnya ke udara (Mulia 1980: 22). Tersirat dari gambar tersebut, bagaimana berkuasanya sang pemimpin terhadap rakyat yang bekerja memindahkan batu tersebut. Di samping itu untuk membuat agar menhir atau arca menhir yang didirikan sebagai lambang penguasa atau pemimpin menjadi kuat, tidak mudah roboh, serta mempunyai kekuatan gaib yang lebih banyak, maka dilakukan pemenggalan kepala. Berdasarkan hasil wawancara yang dilakukan oleh Haris Sukendar (1993), diketahui bahwa biasanya kepala orang yang digunakan untuk korban diambil dari suku luar atau diambil dari suku musuhnya. Kepala tersebut kemudian ditanam di bawah menhir atau arca megalitik (Sukendar 1993: 8).

Dari penggambaran proses upacara pendirian menhir tersebut, dapat diperkirakan besarnya pengaruh dan kekuasaan yang dimiliki oleh 
seorang kepala suku terhadap masyarakat yang dipimpinnya. Seorang penguasa yang berkuasa penuh dengan ditunjang oleh pembantupembantunya dalam masyarakat yang homogen dengan jumlah yang tidak begitu banyak, dapat berbuat apa saja, sesuai dengan kehendaknya. Termasuk salah satunya adalah mendirikan monumen-monumen yang diinginkannya.

\section{Nilai Kharismatik dan Emosi Keagamaan}

Berbeda dengan faktor pemimpin dan kekuasaan terkait dengan alasan terjadinya pelapisan sosial yang dikemukakan oleh Koentjaraningrat, terutama butir $a$ dan $b$ di atas, terdapat kemungkinan diangkatnya seseorang menjadi kepala suku karena adanya nilai-nilai lebih atau nilai kharismatik yang dimiliki oleh orang tersebut. Nilai kharismatik tersebut dapat muncul karena faktor pengetahuan, kewibawaan, serta faktor senioritasnya dalam satu masyarakat. Faktor-faktor tersebut akan memberikan kontribusi yang sangat besar bagi seorang tokoh di dalam masyarakat, yang pada akhirnya akan menjadikan orang tersebut sebagai orang yang disegani dan dihormati oleh masyarakatnya.

Peran seorang kepala suku yang memiliki nilai seperti itu merupakan satu kekuatan yang sangat berpengaruh baik dalam proses transportasi bahan bangunan maupun dalam kegiatan pendirian bangunan megalitik. Rasa hormat dan kharisma yang dimiliki oleh seorang tokoh masyarakat akan mampu menghimpun emosi masyarakat untuk melakukan hal-hal yang berhubungan dengan si tokoh, bahkan keterlibatan individu atau seorang anggota masyarakat dalam kegiatan tersebut mereka anggap sebagai satu pengabdian dan rasa kedekatannya dengan si tokoh yang telah meninggal.

Rasa hormat dan wujud pengabdian terhadap tokoh yang meninggal tersebut sampai sekarang masih terus diwarisi oleh beberapa suku bangsa di Indonesia. Hal tersebut dapat dilihat pada upacara kematian yang berlangsung di Tana Toraja. Bangunan-bangunan megalitik yang mereka dirikan erat hubungannya dengan pelaksanaan kepercayaan aluk to do, yaitu aturan-aturan leluhur atau kepercayaan lama, yang beranggapan bahwa sudah menjadi kewajiban bagi anak cucu untuk mengenang serta memuja arwah-arwah leluhur yang telah menjadi Tomambeli Puang atau dewa. Hal tersebut disebabkan arwah leluhur yang telah diberi wewenang oleh Puang Matua (Sang Pencipta Alam), untuk selalu mengawasi dan memberikan berkat ataupun bencana kepada keturunannya yang masih hidup (Soejono, 1990: 311). Nilai kharismatik dari leluhur tersebut juga tercermin pada saat upacara menarik batu (mangriu batu, weluwatu), dan pengusungan jenazah menuju tempat pemakaman terakhirnya.

Pada prosesi kematian yang berlangsung di Tana Toraja, terlihat seluruh kerabat si tokoh dan masyarakatnya menjadi satu dalam kegembiraan dan kepiluan melepas kepergian si tokoh. Tarian dan nyanyian untuk mengiringi kepergian si tokoh dilakukan oleh penari berpakaian hitam dan dapat diikuti oleh laki-laki maupun perempuan serta berlangsung dari 
pukul 21.00 hingga pukul 03.00 dini hari. Pengantaran jenazah dari rumah ke kuburan adakalanya memakan waktu hingga sepuluh hari. Seluruh keluarga, terutama anaknya mengerahkan segala kekayaannya untuk menghormati si mati, dan sekaligus dijadikan sebagai tanda bakti (Suhadi dan Halina Hambali: 1994/1995: 22-25). Hal ini juga terlihat dari keterlibatan masyarakat yang saling berebutan menggotong erong (peti jenazah) dari rumah duka menuju lokasi pemakaman yang berjarak cukup jauh. Erong digotong di atas sebuah tandu besar secara beramai-ramai dan mereka saling berebut untuk bergantian menggotongnya. Begitu juga dengan upacara tarik batu (menhir) yang nantinya akan didirikan sebagai tanda dari si tokoh yang meninggal. Secara beramai-ramai batu tersebut digotong menempuh jarak berkilo-kilo meter.

Dalam studi etnoarkeologi di Sumba, Nias, Timor Barat, dan Flores dapat disaksikan faktor kharismatik dan emosi keagamaan yang melandasi terbentuknya bangunan-bangunan megalitik. Hal tersebut diperlihatkan oleh keikutsertaan anggota masyarakat secara menyeluruh tanpa melalui perintah, tetapi secara sadar membantu meringankan beban dalam pembangunan megalit atau rumah-rumah adat yang berperan untuk upacara-upacara (peribadatan). Keikutsertaan itu terjadi secara spontan (Sukendar 1996: 117).

Dari contoh tersebut di atas, baik yang berupa prosesi kematian dan upacara menarik batu, maupun dalam upacara mendirikan bangunan megalitik yang diamati oleh Haris Sukendar melalui studi etmoarkeologi, dapat dilihat bagaimana keberadaan nilai kharismatik dan nilai emosi keagamaan yang dimiliki oleh satu masyarakat. Nilai-nilai yang demikian juga merupakan satu wahana dalam proses pengangkutan monumen megalitik. Oleh karena itu, dalam satu masyarakat yang homogen, semangat keagamaan (religius emotion) dan nilai kharismatik merupakan unsur utama yang mampu menarik dan menyatukan spirit masyarakat dalam satu tindakan religius.

Selain tiga faktor di atas, yang juga sangat berperan besar dalam proses pengangkutan bahan/monumen megalitik adalah konsumsi, baik berupa minuman, makanan, dan binatang-binatang kurban. Oleh karena proses pengangkutan bahan/monumen megalitik tersebut memerlukan tenaga manusia dalam jumlah yang banyak, menempuh jarak yang tidak dekat, dan memakan waktu yang lama, maka kurban-kurban yang disembelih untuk pemenuhan konsumsi tentunya juga dalam jumlah yang tidak sedikit. Begitu juga halnya dengan minuman. Dari hasil pengamatan terhadap beberapa suku bangsa seperti Batak, Sunda, Dayak, dan Toraja, hampir semuanya mengenal minuman yang dapat menghangatkan badan yang disebut tuak. Tuak merupakan salah satu minuman tradisional yang dihasilkan dari fermentasi, sehingga menghasilkan minuman yang mengandung alkohol. Tidak tertutup kemungkinan minuman tersebut juga dipergunakan oleh masyarakat pendukung budaya megalitik untuk melakukan intoksidasi yang ditujukan untuk menghilangkan kesadaran diri pelaku upacara. Dalam beberapa kasus dapat dilihat apabila seseorang 
mengkonsumsi makanan yang mengandung lemak tinggi seperti daging babi bersamaan dengan minuman beralkohol tinggi seperti tuak, maka orang tersebut akan cepat mabuk. Dalam suasana yang demikian orang tersebut dapat berbuat apa saja, bahkan dapat memiliki kekuatan yang luar biasa melebihi kemampuan manusia biasa.

\section{PENUTUP}

Dari uraian di atas terlihat bahwa pengangkutan bahan/monumen megalitik yang memiliki ukuran dan bobot yang sangat besar, dapat terjadi karena beberapa faktor. Faktor-faktor tersebut secara garis besar dapat disimpulkan terdiri atas tiga, antara lain faktor alam dan teknologi, faktor kekuasaan, serta faktor nilai kharismatik dan emosi keagamaan.

Faktor pertama dengan teknologi sederhana yang setara dengan tingkat pengetahuan yang ada pada masa itu dan ditambah dengan bentang alam yang mendukung, satu monumen megalitik mampu dipindahkan dari lokasi pembuatannya menuju situs pendiriannya. Kedua dengan adanya faktor kekuasaan, seorang penguasa dalam satu masyarakat yang homogen akan mampu bertindak dan memerintahkan apa saja terhadap rakyatnya. Ketiga adalah dua hal yang saling berkaitan erat yaitu nilai kharismatik yang dimiliki oleh seorang pemimpin di tengah masyarakatnya dan emosi keagamaan yang tumbuh dan berkembang di tengah masyarakat pendukung tradisi budaya megalitik itu sendiri.

Ketiga faktor di atas dengan ditunjang oleh makanan, minuman, kurban, dan dikaitkan dengan keadaan alam serta kajian tentang perkembangan masyarakat di Indonesia. Besar kemungkinan faktor-faktor tersebut memiliki peran dan pengaruh pada saat terjadinya pengangkutan bahan dan monumen megalitik menuju situs pendiriannya di masa lalu. 


\section{KEPUSTAKAAN}

Barbier J.P dan Newton D, 1988. Islands and Ancestors, Indigenous Styles of Southeast Asia. Prestel: The Metropolitan Museum of Art New York

Criado, Felipe, 1991. "We, The Post-Megalithic People...' ", I. Hodder (edt.) The Meanings of Things, Material Culture and Symbolic Expression. One World Archeology.

Geldern, Von Heine, 1945. "Prehistoric Research in The Netherland Indies", dalam Science and Scientis in The Netherland Indies. Pieter Honig dan Frans Verdoorn (ed.).

1974. "The Archaeology and Art of Sumatra", dalam E.M. Loeb (ed.) Sumatra, Its History and People.

Koentjaraningrat, 1972. Beberapa Pokok-Pokok Antropologi Sosial. Jakarta. Penerbit : Dian Rakyat.

1981. Pengantar Ilmu Antropologi. Jakrta. Penerbit: Aksara Baru

Mulia, Rumbi, 1980. Nias: The Only Older Megalithic Tradition In Indonesia. Jakarta: Pusat Penelitian Arkeologi Nasional.

Renfrew Colin dan Paul Bahn, 1996. Archaeology, Theories, Methods and Practice. London: Thames and Hudson Ltd.

Republika, 1997. "Eksotisme Pesta Kematian Di Tana Toraja", Minggu, 27 Juli 1997

Soejono, R.P, 1990. "Jaman Prasejarah di Indonesia", dalam Sejarah Nasional Indonesia, jilid I. Jakarta. PN. Balai Pustaka.

Subagya, Rahmat, 1981. Agama Asli Indonesia. Jakarta. Sinar Harapan dan Yayasan Cipta Loka Caraka

Suhadi, Machi dan Halina Hambali, 1994/1995. Tana Toraja. Jakarta: Proyek Pengembangan Media Kebudayaan. Direktorat Jenderal Kebudayaan

Sutaba, I Made, 1996. "Masyarakat Megalitik Di Indonesia". Evaluasi Hasil Penelitian Arkeologi, Ujungpandang, 20-26 September 1996. 
Sutaba, I Made, 1999. "Keberagaman Dalam Perkembangan Tradisi Megalitik Di Indonesia". Pidato Pengukuhan Jabatan Ahli Peneliti Utama. Jakarta: Pusat Penelitian Arkeologi Nasional. Departemen Pendidikan dan Kebudayaan Republik Indonesia

Sukendar, Haris, 1993. "Arca Menhir Di Indonesia Fungsinya Dalam Peribatan". Disertasi. Program Pasca Sarjana. Universitas Indonesia.

1996. "Dinamika Dan Kepribadian Bangsa Yang Tercermin Dari Tradisi Megalitik Di Indonesia". Jurnal Arkeologi Indonesia No.2. Jakarta. Pusat Penelitian Arkeologi Nasional.

Taylor, Paul Michael and Lorraine V. Aragon, 1991. Art of Indonesia's Outer Islands. The National Museum Of Natural History. Smithsonian Institution. Washington, D.C

Thomas, Julian, 1996. Time, Culture, and Identity an Interpretive Archaeology. Routledge. London and New York.

Yondri, Lutfi, 2005. "Batu Tukuh: Simbol magis pembentukan dan perpindahan kampung di kawasan Lebak Cibedug". Religi Dalam Dinamika Masyarakat. Bandung: Ikatan Ahli Arkeologi Indonesia. 